\title{
Influence of soil treatment methods and standards of mineral fertilizers on growth and development of malt and soil fertility
}

\author{
Munisa Urmanova ${ }^{1, *}$, Abdukodir Kuziev ${ }^{2}$, Dilnavoza Burkhanova ${ }^{1}$, Dilrabo Kadirova ${ }^{1}$, \\ Normamat Namozov ${ }^{1}$, and Nilufar Shadieva ${ }^{1}$ \\ ${ }^{1}$ Tashkent State Agrarian University, University str., 2, Tashkent province, Uzbekistan, 100140 \\ ${ }^{2}$ Tashkent Botanical Park named after Ruzanov, Bogishamol str., 223, Tashkent, Uzbekistan, 100140
}

\begin{abstract}
This article illustrates a number of experiments to conduct research on agronomic techniques of seedling cultivation from the seeds of smooth licorice (Glycyrrhiza Glabra L). The analysis of research results on the effect of irrigation regimes on the growth and development of smooth licorice seedlings, the analysis of experimental work on the effects of smooth licorice irrigation regimens and mineral fertilizer rates on winter wheat yields was carried out. The cost effectiveness of growing seedlings from smooth licorice seeds was also studied by analyzing the results of irrigation procedures, determining the effect of soil processing methods, development and yield of winter wheat sown as a successive crop during cultivation of licorice saplings, and yield of roots in conditions of irrigated typical sierozem soils of the Tashkent province.
\end{abstract}

\section{Introduction}

Today, medicinal licorice is grown all over the world on an area of 43.181 million hectares, and the stock of its biological raw materials is 128.109 million tons $[5,6]$. The products obtained from this plant are widely used in medicine, food industry, cosmetics, light industry and agriculture. Due to the great demand in the world market for raw licorice raw, its natural areas have greatly decreased. In particular, its area in Azerbaijan is 2,200 hectares (of the total area of 3.62\%), Kyrgyzstan - 902 hectares (1.49\%), Kazakhstan 39,875 hectares $(65.69 \%)$, Russia - 1,763 hectares $(2.90 \%)$, Turkmenistan - 10,776 hectares (17.76\%), Tajikistan - 142 hectares $(0.24 \%)$, and in Mongolia - 2,180 hectares $(3.59 \%)[5]$.

In world agriculture, systematic scientific research is being carried out aimed at increasing the areas of cultivated licorice, the natural areas of which are constantly decreasing, in order to meet the need for raw materials, preserve and increase soil fertility, and improve the land reclamation state $[4,6]$. Despite the numerous studies carried out aimed at the use of scientifically grounded crop rotation systems that ensure the preservation and increase of soil fertility and land reclamation state, and obtain an

\footnotetext{
*Corresponding author: m.urmanova76@mail.ru
} 
ecologically clean high and high-quality yield $[1,2,4]$, the reproduction and cultivation of licorice from seeds in our country and the world has not been sufficiently studied [5].

It is important to conduct scientific research on the expansion of licorice crops, which provide for the effective use of irrigated land, natural resources in Uzbekistan, in particular the rational use and protection of plants, relying on scientifically grounded technologies and without disturbing their historically created natural balance [7].

Large-scale measures are being taken in the Republic to increase the cultivation and volumes of industrial processing of licorice $[6,7]$. In this regard, the inclusion of licorice in the system of short rotational crop rotation, the development of methods of optimal agricultural technology, such as rates of irrigation, fertilization and land cultivation in conditions of irrigated typical gray soils is an urgent task $[6,10]$.

Studies on the study of the biological foundations of growing licorice seedlings from seeds, methods, schemes and timing of sowing seeds, the thickness of seedlings were carried out by M. Urmanova [5], the cultivation and growing of seedlings from licorice seeds in the climate of Tashkent, studying methods of planting basal shoots in Mirzachul and the timing of optimal conditions $[6,7]$, crop rotation in the cotton-licorice system in saline soils [3], and improving the reclamation state of soils [4, 8, 9], and conservation of biological diversity of the Fabasea family and their effective use by I. Turopov [11].

M. Urmanova [5-7] and I. Turopov [11, 12] in field experiments studied the influence of licorice on the soil fertility. However, till now, the methods of soil cultivation in the process of obtaining seedlings from licorice seeds, the influence of the norms of mineral fertilizers, the effectiveness of the irrigation regime when growing two-year seedlings of licorice from seeds, as well as the effect of stubble and root residues of licorice on soil fertility and associated with their aftereffect, irrigation regime and fertilization rates of winter wheat.

In this regard, the conduct of scientific work to solve the above problems is of great scientific and practical importance.

\section{Materials and methods}

Field experiments were carried out at the research educational and experimental station of the Tashkent State Agrarian University, located in the Kibray district of Tashkent Province, Uzbekistan. The first experiment consists of 3 options for soil cultivation methods and mineral fertilizers, 9 options which were carried out in 3 short repetitions. The total area of the experimental field was $2,592 \mathrm{~m}^{2}$.

The second experiment was carried out in three repetitions according to the irrigation regime, consisting of 4 options, three options. The experiment on sowing winter wheat after licorice consisted of 12 options; between experiments, a protective zone with a width of one meter remained.

When cultivating licorice seedlings from seeds, to determine their growth and development, the "Recommendation for the propagation of licorice from seeds" by M.M. Badalov was used. When carrying out phenological observations on licorice for the study of underground parts, seed yields were carried out according to the method O. A. Ashurmetov $[5]$.

When undertaking agrochemical analyzes of the soil, the humus content was determined by the method of I.V. Tyurin, total nitrogen, phosphorus, and potassium - according to I.M. Maltseva and P.N. Gritsenko, and the amount of exchangeable potassium according to V.P. Protasov $[6,7,11]$. For the growing season, the pre-irrigation soil moisture was observed, which was compared with the irrigation regimes and the maximum field moisture capacity. The irrigation rates were determined using a Chippoletti spillway $0.5 \mathrm{~m}$ wide (waste water $0.25 \mathrm{~m}$ wide) were measured using Chipolletti water measuring instruments. 
The biomass of licorice and the yield of seedlings, as well as the yield of winter wheat and straw were determined separately by replicates and variants of the experiment. For this, samples were taken from these 3 points of each plot $\left(1 \mathrm{~m}^{2}\right)$ and calculated per hectare. The obtained results on the yield were subjected to mathematical and statistical processing according to the method of B.A. Dospekhov [12] and using the Microsoft Excel program.

Calculations of costs and net profit were carried out according to the book "Methodology for determining the economic efficiency of using the results of scientific research in agriculture."

\section{Results and discussion}

Separately, by years of research, the influence of agrotechnical measures on the growth and development of licorice is described. According to the indicators of phenological observations carried out in the first year on June 1, the results indicate that when subsoiling the soil to a depth of $10-15 \mathrm{~cm}$, the norm is $\mathrm{N}_{40} \mathrm{P}_{60} \mathrm{~K}_{80} \mathrm{~kg} / \mathrm{ha} ; \mathrm{N}_{70} \mathrm{P}_{90} \mathrm{~K}_{110} \mathrm{~kg} / \mathrm{ha} ; \mathrm{N}_{100} \mathrm{P}_{120} \mathrm{~K}_{140}$ $\mathrm{kg} /$ ha plant height was $7.6 ; 7.8$; and $7.6 \mathrm{~cm}$, respectively on options with plowing to a depth of 20-22 cm, respectively, with the norms of mineral fertilizers was $7.8 ; 7.9 ; 8.6 \mathrm{~cm}$; and during autumn plowing to a depth of $30-35 \mathrm{~cm}, 8.9 ; 9.5 ; 9.6 \mathrm{~cm}$. The influence of soil cultivation methods and the norms of mineral fertilizers was observed already in the initial period of the development of licorice. The plant density at the end of the growing season of the first year was about 700.0 - 735 thousand/ha, and the difference between the options was not so great [5] on variants with plowing to a depth of $30-35 \mathrm{~cm}$.

An intensive growth of licorice was observed in comparison with the first year; in this case the intensive growth of the root system can be explained by tillage. The height of plants, corresponding to the norms of mineral fertilizers, was $110.8 ; 115.8 ; 114.1 \mathrm{~cm}$, barrel diameter $6.9 ; 7.4 ; 7.0 \mathrm{~mm}$, the number of leaves reached $22.1 ; 24.0 ; 22.3$ pieces, the number of processes $21.3 ; 22.4 ; 21.1$ pieces, length was $21.8 ; 22.5 ; 20.5 \mathrm{~cm}$ and the number of leaves up to $14.5 ; 15.0 ; 14.1$ where high rates were observed with the use of mineral fertilizers with a rate of $\mathrm{N}_{70} \mathrm{P}_{90} \mathrm{~K}_{110} \mathrm{~kg} / \mathrm{ha}$.

In the third or fourth year of research, even without using mineral fertilizers under the influence of measures taken in previous years, in the variants with autumn plowing to a depth of 30-35 cm. Optimal growth and development of plants was observed, where the stem height was $122.5-139,8 \mathrm{~cm}$, diameter $7.9-11.8 \mathrm{~mm}$, number of leaves $15.8-15.9$ pieces.

The biomass and hay yield of plants were determined over the years of research, depending on the methods of tillage and fertilization rates. At the same time, the highest rates were obtained when plowing to a depth of $30-35 \mathrm{~cm}$ using mineral fertilizers with a rate of $\mathrm{N}_{40} \mathrm{P}_{60} \mathrm{~K}_{80} \mathrm{~kg} / \mathrm{ha}$, where the yield of biomass and hay amounted to 315.4 and 121.8 quintals (q)/ha, respectively. These data indicate an increase in yield by 51.5 and $19.9 \mathrm{q} / \mathrm{ha}$ in comparison with the options for carrying out subsoiling application of higher than the specified rate of mineral fertilizers. On the 8 th variant with the application of mineral fertilizers with the rate of $\mathrm{N}_{70} \mathrm{P}_{90} \mathrm{~K}_{100} \mathrm{~kg} / \mathrm{ha}$, the yield of biomass and hay was 344.7 and $133.1 \mathrm{q} / \mathrm{ha}$, which was 29.3 and $11.3 \mathrm{q} /$ ha higher compared to the application of the norm $\mathrm{N} 40 \mathrm{P} 60 \mathrm{~K} 80 \mathrm{~kg} / \mathrm{ha}$. With the use of mineral fertilizers, the rate of $\mathrm{N}_{100} \mathrm{P}_{120} \mathrm{~K}_{140} \mathrm{~kg} / \mathrm{ha}$, these indicators increased by 1.0 and $0.6 \mathrm{q} /$ ha (Figure 1). 


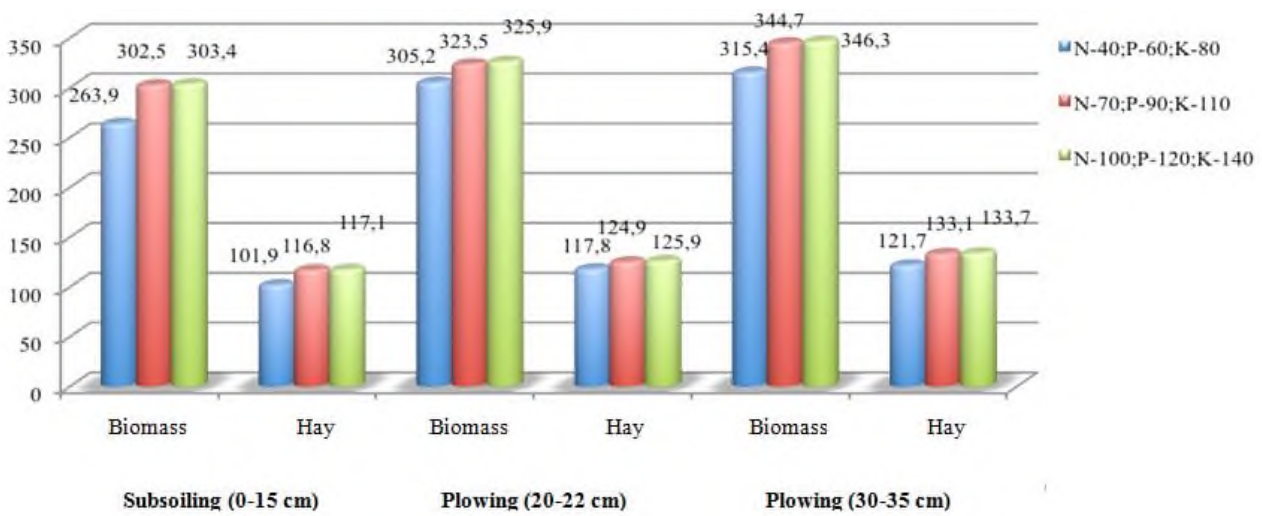

Fig. 1. Influence of tillage methods and fertilization rates on the 4-year average yield of biomass and hay of licorice $(\mathrm{q} / \mathrm{ha})$

When harvesting the rhizomes of licorice selected corresponding to the state standard from one running meter of area was 4-5 pieces, and when translated per hectare, these figures were accounted for $70-80,000$ pieces. When subsoiling the soil to a depth of 10-15 $\mathrm{cm}$ using the norms $\mathrm{N}_{40} \mathrm{P}_{60} \mathrm{~K}_{80} \mathrm{~kg} /$ ha with three repetitions from one plant, the root yield was obtained in dry form 233.1 grams $(0-30 \mathrm{~cm})$, and in the $30-50 \mathrm{~cm}$ layer was $320.4 \mathrm{gr}$ (22.5 - 25.1 tons $/$ ha), where the main part of the root crop was obtained from a $0-30 \mathrm{~cm}$ layer.

When using mineral fertilizers with a rate of $\mathrm{N}_{70} \mathrm{P}_{90} \mathrm{~K}_{100} \mathrm{~kg} /$ ha (on option 2), the yield of plant roots was 248.2 and $367.2 \mathrm{~g}$, respectively (24.0 - 28.8 tons/ha) or, in comparison with the first option, it was higher by 15.1 and $46.8 \mathrm{~g}(1.5-3.7 \mathrm{tons} / \mathrm{ha})$, with an increase in fertilizer rates to $\mathrm{N}_{100} \mathrm{P}_{120} \mathrm{~K}_{140} \mathrm{~kg} / \mathrm{ha}$, these indicators corresponded to 258.8 and $368.1 \mathrm{~g}$ (24.9 - 28.5 tons/ha), which was higher than 25.7 and $47.7 \mathrm{~g}(2.4-3.4$ tons/ha), from the first option and on the second option it was higher compared to $10.6-0.9 \mathrm{~g}(0.9-0.5 \mathrm{ton} / \mathrm{ha})$

The study revealed that the most optimal fertilizer rates are $\mathrm{N}_{70} \mathrm{P}_{90} \mathrm{~K}_{100} \mathrm{~kg} / \mathrm{ha}$, these rates are preserved in other methods of soil cultivation on the fifth option with plowing to a depth of $20-22 \mathrm{~cm}$. In dry form from one root in accordance with soil layers it was 260.7 and $392.5 \mathrm{~g}(25.1-30.0$ tons/ha). With the same tillage (4 varieties) with the use of fertilizers with the rate of $\mathrm{N}_{40} \mathrm{P}_{60} \mathrm{~K}_{80} \mathrm{~kg} / \mathrm{ha}$, these indicators were higher by 20.3 and 22.4 $\mathrm{g} / \mathrm{ha}$, and compared with the second option, where subsoiling was carried out with the use of fertilizer at the optimal rate it was higher by 12.5 and $25.3 \mathrm{~g} / \mathrm{ha}$ (1.1-1.2 tons/ha). In experience, the highest rates were achieved on options with plowing to a depth of $30-35 \mathrm{~cm}$ using the norm $\mathrm{N}_{70} \mathrm{P}_{90} \mathrm{~K}_{110} \mathrm{~kg} / \mathrm{ha}$, and amounted to 276.1 and 418.4 grams per plant, and 26.7 and 32.8 tons per hectare.

The effect of stubble and root residues of four year old licorice on the change in soil fertility was studied, depending on the norms of fertilizers and soil cultivation methods. Before the start of the research in the $0-30$ and $30-50 \mathrm{~cm}$ soil layers, the total amount of humus was 1.010 and $0.998 \%$, nitrogen $0.100-0.098 \%$, phosphorus $-0.164-0095 \%$ and potassium $1.850-1.080 \%, \mathrm{~N}^{-N_{3}} 17.5-11,3 \mathrm{mg} / \mathrm{kg}$ when processing the soil with chisel to a depth of 10-15 cm using fertilizer for two years with a rate of $\mathrm{N}_{40} \mathrm{P}_{60} \mathrm{~K}_{80} \mathrm{~kg} / \mathrm{ha}$ at the end of the experiment, the amount of humus on the upper soil layers was $1.025-1.015 \%$, nitrogen $0.110-0.108 \%$, phosphorus $-0.170-0.098 \%$, potassium $1.750-0.900 \%$ and $\mathrm{N}-\mathrm{NO}_{3}$ $27.5-12.8 \mathrm{mg} / \mathrm{kg}$. However, the total amount of potassium decreased by $0.100-0.100 \%$, and the amount of $\mathrm{N}^{-\mathrm{NO}_{3}}$ increased by $10.0-1.5 \mathrm{mg} / \mathrm{kg}$.

The results on the influence of the irrigation regime not only on the growth, but also on the diameter of its trunk, at high humidity, the trunks with formed high, but thin and, 
accordingly, the irrigation regimes were in the ratio of 5.0; 5.6 and $5.2 \mathrm{~cm}$. The number of leaves under irrigation regime of $80-80-75 \%$ of PPV was relatively higher, which amounted to 15.1 pieces. The number of outgrowths on the trunk was $12.8 ; 12.5 ; 10.5$ pieces, length $8.8 ; 8.2$ and $6.8 \mathrm{~cm}$, and the number of leaves $6.5 ; 6.2 ; 6.0$ pieces.

According to the influence of the irrigation regime not only on the growth, but also on the diameter of its trunk, at high humidity, the trunks with formed high, but thin and, accordingly, the irrigation regimes were in the ratio of $5.0 ; 5.6$ and $5.2 \mathrm{~cm}$. The number of leaves under irrigation regime of $80-80-75 \%$ of PPV was relatively higher, which amounted to 15.1 pieces. The number of branches on the trunk was $12.8 ; 12.5 ; 10.5$ pieces, length $8.8 ; 8.2$ and $6.8 \mathrm{~cm}$, and the number of leaves $-6.5 ; 6.2 ; 6.0$ pieces.

With an increase in the irrigation regime from $70-70-65 \%$ to $75-75-70 \%$ and $80-80$ $75 \%$ of the PPV, a change in the growth and development of plants is observed, the most optimal indicators were obtained on options with an irrigation regime of $75-75-70 \%$ from PPV. This, in turn, was reflected in the harvest of biomass and hay. Standing density of licorice was 698.1-701.2 thousand pieces/ha. In 2009, due to lateral shoots, these indicators reached 1280.0-1300.0 thousand units/ha. While maintaining these laws of measurements, the height of the plants before cutting in accordance with the irrigation regime was 110.8; 100.8 and $93.4 \mathrm{~cm}$. The most optimal results were obtained with an irrigation regime of $75-$ $75-70 \%$ of the PPV.

On variants with an irrigation regime of $75-75-70 \%$ and $70-70-65 \%$ of PPV, the yield of biomass was 69.5 and $60.1 \mathrm{q} / \mathrm{ha}$. The yield of biomass by variants averaged $128.5 ; 128.8$ and $122.3 \mathrm{q} / \mathrm{ha}$, which was 59.4 higher compared to the year; 59.3 and $62.7 \mathrm{q} / \mathrm{ha}$, or almost twice as high. This is due to the biological properties of the plant [7] (Table 1).

Table 1. Influence of the irrigation regime on the yield of biomass and hay of licorice $(\mathrm{kg} / \mathrm{ha})$

\begin{tabular}{|c|c|c|c|c|c|c|c|}
\hline \multirow{2}{*}{ 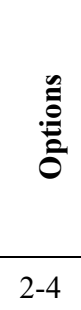 } & \multirow{2}{*}{ 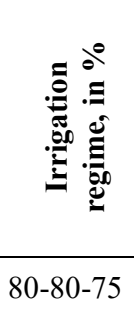 } & \multicolumn{2}{|c|}{ Biomass } & \multirow{2}{*}{ 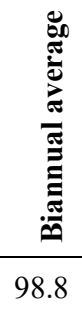 } & \multicolumn{2}{|c|}{ Hay } & \multirow{2}{*}{ 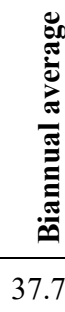 } \\
\hline & & 69.1 & 128.5 & & 26.5 & 49.0 & \\
\hline $6-8$ & $75-75-70$ & 69.5 & 128.8 & 99.1 & 27.0 & 49.4 & 38.2 \\
\hline $10-12$ & $70-70-65$ & 60.1 & 122.3 & 91.2 & 23.8 & 46.5 & 35.0 \\
\hline
\end{tabular}

After the end of this experiment (on these plots), the influence of the irrigation regime and the rates of mineral fertilizers on the wheat yield was studied.

When establishing the norms for watering licorice, the periods before the formation of complex leaves, before flowering and ripening were taken into account, and on winter wheat - the periods of tillering, booting and milky-wax ripeness, where the calculated soil layers were $0-50 ; 0-70$ and $0-50 \mathrm{~cm}$. [6] It should be noted that in the variants with irrigation regime $80-80-75 \%$ of the PPV, the irrigation rates of licorice in and winter wheat were 700.8-910.5 and $560.4-729,5 \mathrm{~m}^{3} / \mathrm{ha}$, and the irrigation norms are $3871.5-3848.3$ and $3,349.9-3,258.2 \mathrm{~m}^{3} / \mathrm{ha}$. In the variants with an irrigation regime of $75-75-70 \%$ of the PPV, the irrigation rates slightly increased and amounted to $725.5-1,110.5$ and $612.8-$ $923.0 \mathrm{~m}^{3} / \mathrm{ha}$, and the irrigation rates were equal to $3,811.6-3817,2$ and $3,164.7-3,179.8$ $\mathrm{m}^{3} / \mathrm{ha}$.

Growing licorice seedlings from seeds, where the influence of the stubble and root residues of licorice left in the field on the germination of winter wheat, plant density, the 
number of common and productive stems, the number of grains in one ear, the weight of 1000 pieces of grains, quality indicators and grain yield is determined, changes in soil fertility.

After sowing winter wheat seeds on October 15, observations began 7 days later (10.10 $\mathrm{pm}$ ) and were repeated every 3 days. It was revealed that in the control (1) variant (for 2 years before winter wheat, nothing was sown), in accordance with the observation periods in the similarity of seed growth was $17.5 ; 20.5 ; 48.1 ; 66.1 ; 90.5 \%$, and in option 2 these indicators (under the influence of the remains of leaves, stems and roots of licorice) were 0.6 higher; $0.7 ; 2.0 ; 2.0$ and $1.8 \%$.

Similar indicators were obtained for other irrigation regimes and fertilizer rates. When sowing winter wheat seeds on October 17, observations began on October 24, where, in accordance with the observation dates, the indicators were $18.9 ; 26.5 ; 46.1 ; 65.1$ and $91.2 \%$ (on control), relatively high rates regardless of the irrigation regime under the influence of the last influence of licorice were obtained in the variants with the use of fertilizers with the rate of N150P100K75 kg/ha and amounted to (2) $20.5 ; 28.8 ; 48.2 ; 67.4 ; 92.8 \%$ and that by $1.6 ; 3.2 ; 2.1 ; 2.3 ; 0.6 \%$ higher compared to control.

This means that the level of germination of winter wheat seeds depends on the amount of stubble and root residues, as well as the norms of mineral fertilizers.

In the first option, with an irrigation regime of $80-80-75 \%$ of the PPV, with the use of fertilizers at the rate of $\mathrm{N}_{200} \mathrm{P}_{140} \mathrm{~K}_{100} \mathrm{~kg} / \mathrm{ha}$, at the beginning of the growing season of winter wheat, the density of standing was $340.1 \mathrm{~m}^{2} /$ pieces, and in the option with the use of $\mathrm{N}_{150} \mathrm{P}_{100} \mathrm{~K}_{70} \mathrm{~kg} / \mathrm{ha}$ a relatively high figure was $335.6 \mathrm{~m}^{2} /$ pieces. After wintering, these indicators were respectively 299.1 and $304.1 \mathrm{~m}^{2} /$ pieces, the number of lost seedlings -9.7 and $9.0 \%$. At the end of the growing season, these indicators were 285.1 and 295.6 $\mathrm{m}^{2} /$ piece.

It should be noted that wintering of winter wheat will only affect the preceding crop. The influence of the irrigation regime and fertilization rates was almost not observed.

Depending on the irrigation regime $80-80-75 \%$ and the norms of mineral fertilizers, the height of winter wheat in the period of milk-wax and full ripeness was $90.5 ; 89.4 ; 88.1 \mathrm{~cm}$ \& 98.4; $91.2 ; 92.1 \mathrm{~cm}$. At the same time, a relatively high indicator was observed when using mineral fertilizers $\mathrm{N}_{150} \mathrm{P}_{100} \mathrm{~K}_{75} \mathrm{~kg} / \mathrm{ha}$ and was $10 \mathrm{~cm}$ higher compared to the control. In this variant, the total number of stems was $530.5 \mathrm{~m}^{2} /$ pieces. That is 30.4 and 33.8 $\mathrm{m}^{2} /$ piece more compared to the control. The highest height of winter wheat $(98.4 \mathrm{~cm})$ was obtained when using an irrigation regime of $80-80-75 \%$ of PPV and mineral fertilizers with a rate of $\mathrm{N}_{150} \mathrm{P}_{100} \mathrm{~K}_{75} \mathrm{~kg} / \mathrm{ha}$, an increase in the number of productive stems was observed in option (6) with the use of fertilizers in the same norms, but with an irrigation regime of 75$75-70 \%$ of the PPV. It was found that if in 1-year to apply fertilizer rates $\mathrm{N}_{150} \mathrm{P}_{100} \mathrm{~K}_{75} \mathrm{~kg} / \mathrm{ha}$, and 2-year $-\mathrm{N}_{200} \mathrm{P}_{140} \mathrm{~K}_{100} \mathrm{~kg} / \mathrm{ha}$, and assign an irrigation regime of $75-75-70 \%$ of the PPV, then optimal conditions are created for growth, development and quality improvement.

This means that under the influence of licorice, at low rates of fertilizers, high efficiency was obtained. The indicator of this (6) option (57.6 q/ha) compared to the control is higher by $8.3 \mathrm{q} / \mathrm{ha}$, and compared to the options for the irrigation regime $80-80-75 \%$ and $70-70-65 \%$ of the PPV, application of fertilizers in an equivalent amount, higher by 1.1 and $3.6 \mathrm{q} / \mathrm{ha}$. Under the influence of the remains of licorice in the soil in 1 year, the most effective fertilizer rates are $\mathrm{N}_{150} \mathrm{P}_{100} \mathrm{~K}_{75} \mathrm{~kg} / \mathrm{ha}$, and under the subsequent influence $\mathrm{N}_{200} \mathrm{P}_{140} \mathrm{~K}_{100} \mathrm{~kg} / \mathrm{ha}$. The obtained data on grain yield for 2 years, in all variants, including the control one, relatively high grain yields were obtained with an irrigation regime of 75 $75-70 \%$ of the PPV. The highest grain yield $(55.8 \mathrm{q} / \mathrm{ha})$ was obtained with fertilizers $\mathrm{N}_{200} \mathrm{P}_{140} \mathrm{~K}_{100} \mathrm{~kg} / \mathrm{ha}$. Additional yield from fertilization $(1.5 \mathrm{q} / \mathrm{ha})$, obtained from the influence of licorice and subsequent influences of $7.7 \mathrm{q} / \mathrm{ha}$, and from the irrigation regime was $5.1 \mathrm{q} /$ ha. 
Relatively high indicators of the amount of protein and gluten in the composition of the grain were also obtained with irrigation of $75-75-70 \%$ of the PPV using fertilizers (in 1 year) $\mathrm{N}_{150} \mathrm{P}_{100} \mathrm{~K}_{75} \mathrm{~kg} / \mathrm{ha}$ and (in 2 years) $\mathrm{N}_{200} \mathrm{P}_{140} \mathrm{~K}_{100} \mathrm{~kg} / \mathrm{ha}$ and were equal to $15.0 \%$ and 0.86 tons; $28.0 \%$ and 1.8 tons, as well as 14.8 and 0.84 tons; $28.2 \%$ and 1.3 tons.

After harvesting two summer seedlings of licorice, when studying the change in soil fertility under the influence of its residues and fertilization rates (depending on the irrigation regime), on options with an irrigation regime of $75-75-70 \%$ of the PPV using fertilizer with a rate of $\mathrm{N}_{150} \mathrm{P}_{100} \mathrm{~K}_{75} \mathrm{~kg} / \mathrm{ha}$ (6-option), the amount of humus, corresponding to the soil layers, was $0.920-0.996 \%$, total nitrogen $-0.130-0.099$; phosphorus $-0.176-$ 0.096 and potassium $1.810-0.990 \%$, and it was revealed that compared with the control, these indicators increased by $0.118-0.008 ; 0.040-0.001 ; 0.007-0.001 \%$ and the initial state - by $0.028-0.000 ; 0.030-0.001 ; 0.016-0.001 \%$, but the amount of total potassium decreased by $0.040-0.010 \%$. In our opinion, the reason for the decrease in the amount of total potassium in the soil is that licorice is demanding of this nutrient.

\section{Conclusion}

In conclusion, it has been determined that in order to preserve and increase soil fertility, as well as to obtain a stable crop yield in the conditions of typical serozem soils of the Tashkent province, licorice can be introduced into the crop rotation system, the natural areas of which are constantly decreasing on a global scale.

It has been determined that to obtain a high yield that meets the requirements of the state standard from 4-year-old licorice grown from seeds $(0-30 \mathrm{~cm}) 26.7$ tons/ha and $(30-$ $50 \mathrm{~cm}) 32.6$ tons $/$ ha, optimal conditions are created when plowing to a depth of 30-35 cm using mineral fertilizers with a rate of $\mathrm{N}_{70} \mathrm{P}_{90} \mathrm{~K}_{110} \mathrm{~kg} / \mathrm{ha}$.

To obtain a relatively high yield on average for 2 years of biomass ( 99.1 tons/ha), hay (38.2 tons/ha) when cultivated from licorice grown from seeds should be irrigated according to the irrigation regime $75-75-70 \%$ of PPV. After digging two-year old licorice seedlings grown from seeds, the remaining root residues in the $0-30 \mathrm{~cm}$ layer of soil amounted to 59.8 tons/ha, in the $30-50 \mathrm{~cm}$ layer 26.8 tons/ha, and only 122.8 tons/ha, where the nitrogen content in their composition was $32.9 \mathrm{~kg} / \mathrm{ha}$.

On the variants where wheat was grown permanently, regardless of the irrigation regime, the humus content decreased by $0.092 \%$ compared to the initial data $(1.010 \%)$. Relatively high rates were obtained when sowing winter wheat after two-year-old seedlings of licorice, when irrigated with an irrigation regime of $75-75-70 \%$ of PPV using mineral fertilizers with a rate of $\mathrm{N}_{150} \mathrm{P}_{100} \mathrm{~K}_{75} \mathrm{~kg} / \mathrm{ha}$ and amounted to $1.038 \%$, which is $0.118 \%$ higher compared to control and $0.028 \%$ higher than the baseline.

On variants with sowing wheat for two years without sowing licorice in accordance with irrigation regimes, the grain yield was $47.7 ; 48.3$ and $46.0 \mathrm{q} / \mathrm{ha}$. Relatively high rates were obtained with an irrigation regime of $75-75-70 \%$ of the PPV, with the use of fertilizers in the first year with a rate of $\mathrm{N}_{150} \mathrm{P}_{100} \mathrm{~K}_{75} \mathrm{~kg} / \mathrm{ha}$, and in the second year with a rate of $\mathrm{N}_{200} \mathrm{P}_{140} \mathrm{~K}_{100} \mathrm{~kg} / \mathrm{ha}$ and amounted to $57.6-53.9 \mathrm{q} / \mathrm{ha}$. The average grain yield for two years was $55.8 \mathrm{q} / \mathrm{ha}$, where mineral fertilizers were applied at the rate of $\mathrm{N}_{200} \mathrm{P}_{140} \mathrm{~K}_{100} \mathrm{~kg} / \mathrm{ha}$. At the same time, the additional yield from the catch crop was $7.5 \mathrm{q} / \mathrm{ha}$, from fertilizers -1.5 $\mathrm{q} / \mathrm{ha}$ and from the irrigation regime, $5.1 \mathrm{q} / \mathrm{ha}$.

When cultivating winter wheat after two summer seedlings of licorice with the use of mineral fertilizers with a rate of $\mathrm{N}_{200} \mathrm{P}_{140} \mathrm{~K}_{100} \mathrm{~kg} /$ ha with an irrigation regime of $75-75-70 \%$ of the PPV, the dry weight of crop and root residues in the soil was $36.3 \mathrm{q} / \mathrm{ha}$, the total nitrogen in their composition was $1,600 \%$, phosphorus 1,280 and potassium $2,100 \%$. These indicators were respectively higher by $0.310 ; 0.450$ and $0.290 \%$ compared to control. 
To grow two summer seedlings from seeds and a high yield of roots from a four-yearold licorice and to increase soil fertility in typical sierozem conditions of the Tashkent province, it is recommended to plow to a depth of $30-35 \mathrm{~cm}$ using mineral fertilizers at a rate of $\mathrm{N}_{70} \mathrm{P}_{90} \mathrm{~K}_{110} \mathrm{~kg} / \mathrm{ha}$; when growing two-year seedlings from seeds, it is recommended to irrigate with a regime of $75-75-70 \%$ PPV, and to obtain a high yield of grain of winter wheat after two summer seedlings of licorice, irrigate with an irrigation mode of 75-75$70 \%$ of PPV, using mineral fertilizers as the norm $\mathrm{N}_{150} \mathrm{P}_{100} \mathrm{~K}_{75} \mathrm{~kg} / \mathrm{ha}$.

\section{References}

1. N. Teshaev, B. Mamadaliyev, A. Ibragimov, S. Khasanov, InterCarto. InterGIS 26(3), 324-333 (2020)

2. S. Isaev, I. Begmatov, G. Goziev, S. Khasanov, IOP Publishing 883(1), 012080 (2020)

3. S. K. Isaev, R. U. Rakhmonov, S. S. Tadjiev, G. I. Goziev, S. Z. Khasanov, IOP Publishing 614(1), 012147 (2020)

4. R. A. Kulmatov, S. A. Adilov, S. Khasanov, IOP Publishing 614(1), 012149 (2020)

5. M. N. Urmanova, Uzbek Journal of Agriculture 8, 27-28 (2011)

6. M. N. Urmanova, Uzbek Journal of Agriculture 7, 26 (2012)

7. M. Urmanova, European journal of research 1(11-12), 152-155 (2018)

8. I. Aslanov, S. Khasanov, Y. Khudaybergenov, M. Groll, Ch. Opp, F. Li, E. Ramirez Del-Valle, E3S Web of Conferences 227, 02005 (2021)

9. A. Jumanov, S. Khasanov, A. Tabayev, G. Goziev, U. Uzbekov, E. Malikov, IOP Publishing 614(1), 012150 (2020)

10. L. Tamene, T. Amede, J. Kihara, D. Tibebe, S. Schulz, Technical Report. CIAT, 49 (2017)

11. I. Turopov, D. Kodirova, M. Saidova, N. Namozov, D. Burkhanova, Soil climatology, 95 (Sharq Press, Tashkent, 2017)

12. I. Turopov, B. Kamilov, Soil Physics, 16 (TSAU Press, Tashkent, 2014) 